\title{
Rubella-neutralizing and Haemagglutinin-inhibiting Antibodies in Children of Different Ages
}

\author{
T. BROWN,* B.SC. ; M. H. HAMBLING, † M.D., M.C.PATH., DIP.BACT, ; B. M. ANSARI, $\ddagger$ M.B., M.R.C.P.ED., D.C.H.
}

\begin{abstract}
Cummary : Rubella neutralization and haemagglutinin$N$ inhibition tests were used to determine the incidence of rubella antibodies in the sera of 235 children and adolescents aged 1 month to 20 years. The tests showed good agreement in the detection of rubella antibodies resulting from acute infection. Maternal antibodies became undetectable within six months after birth. The proportion of children possessing rubella antibodies was found to be about $23 \%$ by the age of 5 years, rising, sharply to $80 \%$ in the $6-12$ years age group and $83 \%$ in the 13-20 years age group. Results indicate that the incidence of rubella infection may be higher in females than in males. The correlation between statements concerning a past history of rubella and immune status was poor, particularly in the older age groups. Any policy for vaccination against rubella must take into account the difficulties of identifying nonimmune persons in a large population.
\end{abstract}

\section{Introduction}

The use of the rubella neutralization test and the haemagglutinininhibition test has resulted in the accumulation of much information about the immune status of normal populations. Because of the risk of fetal abnormalities following infection with rubella virus during early pregnancy many such antibody surveys have been concerned with women of child-bearing age (Public Health Laboratory Service, 1968 ; Vesikari, Vaheri, and Kauppinen, 1968). More recently, the incidence of rubella antibodies in younger age groups has also been reported (Enders-Ruckle and Lindemann, 1969 ; Chagnon, Davignon, and Pavilanis, 1969). It seems likely that rubella vaccines will soon be available and the optimal age for their administration will have to be decided. Before such a decision can be made, knowledge of the immune status of the population of all age groups is essential.

This report presents the results of an investigation of the incidence of rubella neutralizing and haemagglutinin-inhibiting antibodies in children living in and around the city of Leer.. At the same time a comparison was made of the effectiveness of the two tests for the detection of rubella antibody.

\section{Materials and Methods}

Sera.-Blood specimens were obtained from 235 children and adolescents admitted with a variety of complaints to the infectious diseases department of Seacroft Hospital, Leeds, between April 1967 and May 1968. Patients presenting with a rash were excluded from the investigation. When received at the laboratory the sera were separated and stored at $-40^{\circ} \mathrm{C}$.

Neutralization Test.-The West Point strain of rubella virus was used as the antigen. The technique for the neutralization

* Research Assistant, Department of Virology, Institute of Child Health, Guildford Street, London W.C.1. Formerly Public Health Laboratory, York Road, Leeds LS15 7TR.

† Consultant Virologist, Public Health Laboratory, York Road, Leeds LS15 7TR.

¥ Medical Assistant, Infectious Diseases Unit, Seacroft Hospital, Leeds LS14 6UH. test was based on that of Hutchinson and Thompson (1965), with the following modifications. After inoculation of the R.K. ${ }_{13}$ cell cultures the maintenance medium was not changed and the final readings were made on the fifth day. Neutralization was considered to have occurred in those cultures which showed a definite inhibition of virus cytopathic effect, and virus neutralizing (V.N.) antibody titres were expressed as the reciprocal of the initial serum dilution.

Haemagglutinin-inhibition (H.A.I.) Test.-The method of Stewart et al. (1967) adapted for use in W.H.O. Perspex plates was used. Pigeon erythrocytes (Peetermans and Huygelen, 1967) were used as a $0.24 \%$ suspension in place of day-old chick cells. The haemagglutinin was supplied by the Standards Laboratory, Central Public Health Laboratory, Colindale. The haemagglutinin (H.A.) titre was determined before each batch of tests and was expressed as the highest dilution causing complete agglutination of pigeon erythrocytes. Four H.A. units were used in the H.A.I. tests.

Sera were treated with $25 \%$ kaolin, adsorbed with a $50 \%$ suspension of pigeon red blood cells and inactivated at $56^{\circ} \mathrm{C}$. for 30 minutes. Appropriate controls were included in each batch of tests, and the serum H.A.I. titres were read as the reciprocal of the highest initial dilution causing complete inhibition of haemagglutination.

\section{Results}

The distribution of H.A.I. and V.N. antibodies in the different age groups is shown in Fig. 1. Of the 19 sera from infants below the age of 4 months $14(73.7 \%)$ were found to have detectable levels of H.A.I. antibody, and 11 of these $(57.9 \%)$ also had V.N. antibody. These antibodies decreased rapidly with age, disappearing after six months, and were presumably maternal in origin. From the age of 1 year the proportion of seropositives increased with age. Four of 47 sera $(8.5 \%)$ from children aged $1-2$ years possessed both H.A.I. and V.N. antibodies. Of the 41 sera from the 3-5 years age group $10(24.4 \%)$ had H.A.I. antibody and $9(22 \%)$ had V.N. antibody. Both H.A.I. and V.N. antibodies were present in

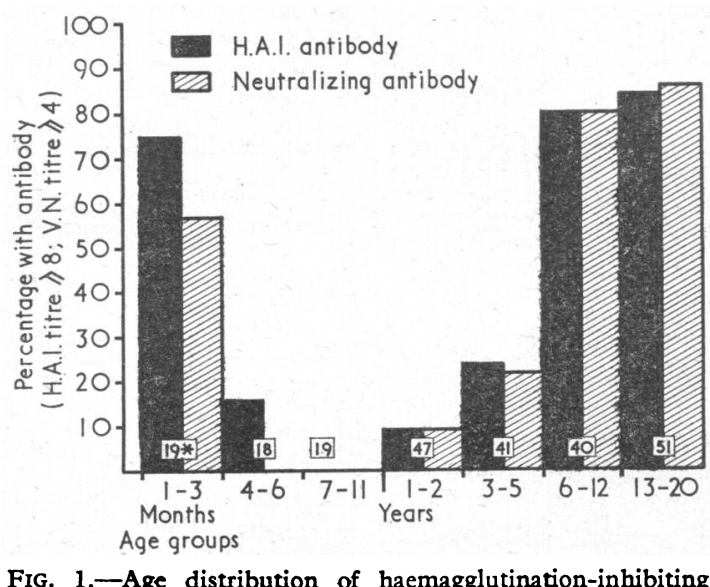

Fise distribution of haemagglutination-inhibitin Asterisk indicates number of sera tested in each group. 
32 of 40 sera (80\%) from children aged 6-12 years, and of the 51 sera from children and adolescents of the 13-20 years age group H.A.I. antibody was found in $42(82.4 \%)$ and V.N. antibody in $43(84.3 \%)$.

A comparison was made between the H.A.I. and V.N. antibody titres of sera from 179 children over the age of 1 year -that is, those in which the rubella antibodies detected were presumed to be the result of postnatal infection. H.A.I. antibody titres were usually considerably higher than the corresponding V.N. antibody titres (Fig. 2). With the exception of two sera, the presence or absence of antibody was detected with both tests, representing a $98.9 \%$ correlation.

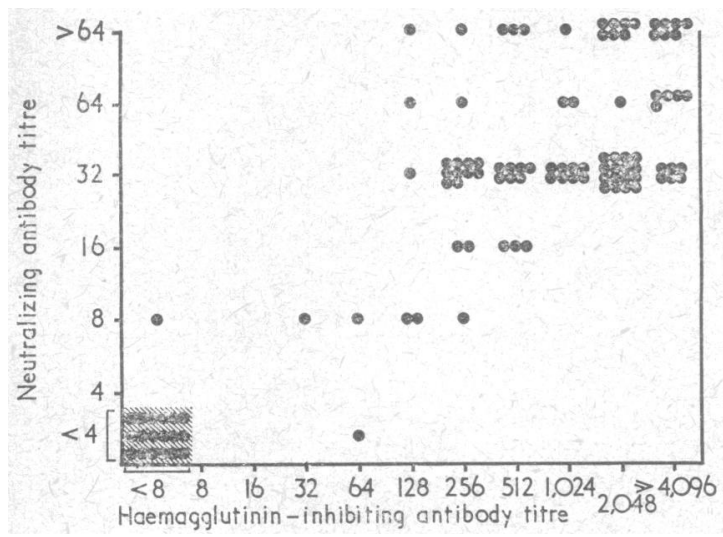

FIG. 2.-Rubella haemagglutinin-inhibiting and neutralizing antibody titres of sera from subjects aged 1-20 years.

The distribution of rubella H.A.I. antibodies in the three main age groups according to sex is shown in Table $\mathrm{I}$.

TABLE I.-Immune Status According to Sex*

\begin{tabular}{c|c|c|c|c}
\hline \multirow{2}{*}{$\begin{array}{c}\text { Age in } \\
\text { Years }\end{array}$} & \multicolumn{2}{|c|}{ Males } & \multicolumn{2}{|c}{ Females } \\
\cline { 2 - 4 } & $\begin{array}{c}\text { Total } \\
\text { No. }\end{array}$ & $\begin{array}{c}\text { No. with } \\
\text { Antibody }\end{array}$ & $\begin{array}{c}\text { Total } \\
\text { No. }\end{array}$ & $\begin{array}{c}\text { No. with } \\
\text { Antibody }\end{array}$ \\
\hline $1-5$ & 43 & $4(9 \cdot 3)$ & 45 & $10(22 \cdot 2)$ \\
$6-12$ & 24 & $18(75 \cdot 0)$ & 16 & $14(87 \cdot 5)$ \\
$13-20$ & 16 & $11(68 \cdot 7)$ & 35 & $31(88 \cdot 6)$ \\
\hline
\end{tabular}

* Sera with H.A.I. antibody titre $\geqslant 8$. (Percentages in Tables I-III are expressed in parentheses.)

In the 1-5 years age group $9.3 \%$ of males and $22.2 \%$ of females were found to be seropositive. In the 6-12 years age group the corresponding figures were $75 \%$ and $87.5 \%$, while in the 13-20 years age group they were $68.7 \%$ and $88.6 \%$ respectively.

A definite past history of rubella was obtained for 56 of 179 patients between the ages of 1 and 20 years. Laboratory evidence of infection was obtained in $40(71.4 \%)$ of these cases (Table II). Conversely, 103 children were stated not to have had rubella in the past, and in $37(35.9 \%)$ of these laboratory evidence of infection was demonstrated.

TABLE II.-Relation Between History of Rubella and Immune Status*

\begin{tabular}{c|c|c|c}
\hline $\begin{array}{c}\text { History of } \\
\text { Previous } \\
\text { Rubella } \\
\text { Infection? }\end{array}$ & $\begin{array}{c}\text { No. of } \\
\text { Sera Tested }\end{array}$ & $\begin{array}{c}\text { No. with } \\
\text { Antibody }\end{array}$ & $\begin{array}{c}\text { No. without } \\
\text { Antibody }\end{array}$ \\
\hline $\begin{array}{c}\text { Yes } \\
\text { No } \\
\text { Not known }\end{array}$ & 56 & $\begin{array}{r}40(71 \cdot 4) \\
37(35 \cdot 9) \\
7(35 \cdot 0)\end{array}$ & $\begin{array}{r}16(28 \cdot 6) \\
66(64 \cdot 1) \\
13(65 \cdot 0)\end{array}$ \\
\hline \multicolumn{2}{l}{$\begin{array}{l}103 \\
20\end{array}$} & Sera from patients aged 1-20 years inclusive.
\end{tabular}

An attempt was made to correlate the accuracy of statements regarding a past history of rubella infection, indicated by serological studies, with age. The results (Table III) show that after elimination of those whose past history was not known the accuracy of these statements-regardless of when infection actually occurred-decreased with age.
TABLE III.-Laboratory Confirmation of History of Rubella According

\begin{tabular}{c|c|c|c}
\multicolumn{3}{|c|}{ to Age } \\
\hline Age in Years & Total No. & $\begin{array}{c}\text { Past History } \\
\text { Confirmed }\end{array}$ & $\begin{array}{c}\text { Past History } \\
\text { Not Confirmed }\end{array}$ \\
\hline $1-5$ & 78 & $61(78 \cdot 2)$ & $17(21 \cdot 8)$ \\
$6-12$ & 36 & $22(61 \cdot 1)$ & $14(38 \cdot 9)$ \\
$13-20$ & 45 & $26(57 \cdot 8)$ & $19(42 \cdot 2)$
\end{tabular}

Patients whose past history of rubella was not known were excluded.

\section{Discussion}

Maternal rubella antibodies were found to be present in a high proportion of babies up to 3 months after birth, but were no longer detected after the age of 6 months. From the age of 1 year onwards, the proportion of seropositive patients rose to a level of about $83 \%$ in the $13-20$ year age group. These results are broadly in agreement with those of other workers, though some differences in detail emerge. Thus Tóth (1968) found a comparatively high proportion of seropositives (43\%) in the 1-5 year age group, while Sever et al. (1965) indicated a low proportion (approximately $30 \%$ ) of seropositives in the 6-10 years age group. In our corresponding age groups (1-5 and 6-12 years) these figures were $15 \%$ and $80 \%$ respectively.

Previous studies have shown that the V.N. and H.A.I. tests show good agreement in the detection of rubella antibodies (Field et al., 1967 ; Lennette, Schmidt and Magoffin, 1967). The present investigation confirms this. Rubella H.A.I. titres tend to be considerably higher than the corresponding V.N. titres, but the difference between these titres is not always consistent, and some overlapping may be shown. From our series, 48 sera with a V.N. titre of 32 had H.A.I. titres ranging from 128 to $>4,096$, whereas 6 sera with a V.N. titre of 8 had H.A.I. titres ranging from $<8$ to 256 . Maternal V.N. antibody declined at a higher rate than the H.A.I. antibody. H.A.I. antibody alone was found in 6 of 37 sera from children aged 1-6 months, but in only one of the 198 sera from the remaining age groups. It is likely that these results reflect a difference in the sensitivity of the two techniques, the H.A.I. test being more sensitive than the V.N. test, particularly for detecting the comparatively low titres of maternal antibody in the sera of infants. However, the possibility that a difference may exist in the nature of the H.A.I. and V.N. antibodies cannot be excluded.

The results of this study confirm previous reports (Sever et al., 1965) that rubella occurs mainly among children of primary school age, though infants below the age of 5 years may be infected more often than was believed on clinical grounds (Dudgeon, 1967). The particularly high level of immunity in Leeds children of the 6-12 years age group is interesting in view of an earlier study of the normal adult female population of the same area (P.H.L.S., 1968). Neutralizing antibody to rubella was found in $96 \%$ of these women, and it now appears that infection was acquired in most cases during childhood. The higher degree of immunity of the Leeds population compared with that of London, for example $(80 \%$ level of immunity), is difficult to explain (P.H.L.S., 1968), but such variations are probably at least partly due to sociological differences between the communities investigated.

The data presented in Table I seem to indicate a difference in the frequency of rubella infection according to sex. In each of the three age groups the incidence of sero-immunity in females was consistently higher than that in males. This is in agreement with the reports of Hillenbrand (1956) and Watson and McDonald (1963), which described higher incidences of clinical rubella among females compared with males. However, the numbers of sera involved in our study are small and subject to sampling errors. The study by Enders-Ruckle and Lindemann (1969), involving a much larger number of sera, showed no significant over-all difference in immune status between the sexes. 
It is confirmed that little reliance can be placed on statements concerning a past history of rubella. In this series about one-third of all firm statements were proved to be wrong on subsequent laboratory investigation. The histories, mostly obtained from parents, were most accurate for the 1-5 years age group. Similar findings have been reported by other workers (Vesikari et al., 1968). This lack of correlation between statements concerning a past history of rubella and serological studies may be ascribed to the difficulty in diagnosis of rubella which is often simulated clinically by other infections (Krugman, 1965). Ignorance of infection may also be due partly to the occurrence of subclinical attacks, and, to a certain extent, failure to remember the occurrence of clinical infection many years in the past.

The results of this and previous serological studies of children seem to raise a number of important problems concerning vaccination against rubella. Several vaccines have been developed and the results of preliminary clinical trials published (Proceedings of the 23rd Symposium on Microbiological Standardization, Rubella Vaccines, 1969). Before these vaccines become freely available the age at which they are to be administered must be decided. As yet, insufficient data have been published concerning the possible transmission of vaccine strains of rubella virus across the placenta and the teratogenic effects of these strains on the fetus. Consequently, the vaccination of adult women will involve the prevention of pregnancy immediately before and after administration of the vaccine. If children are to be vaccinated, it must be taken into consideration that the majority are already naturally immune by the age of $10-15$ years, and mass vaccination at this stage may be regarded as impracticable or uneconomical. The selection of children on the basis of past histories cannot be relied on, and the alternative screening of all children to detect immune status prior to vaccination would be very laborious. The vaccination of infants below the age of 5 years may be more logical, as this age group has the lowest level of natural immunity. In this case, however, vaccine-induced immunity may not be sufficient to afford protection into adulthood, and it may be necessary to revaccinate in later years.

We wish to thank Dr. J. A. Dudgeon for advice and encouragement, Dr. J. Stevenson and his staff for obtaining the serum samples, and Dr. Patricia Bradstreet, of the Standards Laboratory (P.H.L.S.), Colindale, for providing the rubella haemagglutinin.

Reprint requests to $\mathrm{Mr}$. T. Brown, Department of Bacteriology, University of Aberdeen, Aberdeen AB9 2ZO.

\section{REFERENCES}

Chagnon, A., Davignon, L., and Pavilanis, V. (1969). In Proceedings of the 23rd Symposium on Microbiological Standardization, Rubella Vaccines, London, November 1968. Basle, Karger.

Dudgeon, J. A. (1967). Public Health (London), 81, 268.

Enders-Ruckle, G., and Lindemann, L. (1969). In Proceedings of the $23 \%$ Symposium on Microbiological Standardization, Rubella Vaccines, London, November 1968. Basle, Karger.

Field, A. M., Vandervelde, E. M., Thompson, K. M., and Hutchinson, D. N. (1967). Lancet, 2, 182 .

Hillenbrand, F. K. M. (1956). Lancet, 2, 64.

Hutchinson, D. N., and Thompson, K. M. (1965). Monthly Bulletin of the Ministry of Health and the Public Health Laboratory Service, 24,385 .

Krugman, S. (1965). Archiv für die gesamte Virusforschung, 16, 477. Lennette, E. H., Schmidt, N. J., and Magoffin, R. L. (1967). Fournal of Immunology, 99, 785 .

Peetermans, J., and Huygelen, C. (1967). Presse Médicale, 75, 2177. Public Health Laboratory Service (1968). British Medical fournal, 3, 203.

Sever, J. L., et al. (1965). Pediatrics, 35, 996.

Stewart, G. L., et al. (1967). New England fournal of Medicine, 276,

Tóth, M. (1968). Acta Microbiologica Academiae Scientiarum Hungaricae, 15, 119

Vesikari, T., Vaheri, A., and Kauppinen, M. A. (1968). Annales Medicinae Experimentalis et Biologiae Fenniae, 46, 109.

Watson, G. I., and McDonald, J. C. (1963). British Medical fournal, 2, 419 .

* Consultant Chest Physician, Chest Service, Dundee.

† Consultant Physician, Maryfield Hospital, Dundee.

₹ Medical Assistant, Chest Service, Dundee.

Medical Registrar, Maryfield Hospital, Dundee.

Medical Registrar, Chest Service, Dundee.

\section{Introduction}

Optimal antibiotic regimens for chronic recurrent mucopurulent bronchitis are difficult to assess, being complicated by the plethora of antibiotics available. It is still uncertain whether patients on chemoprophylaxis during the winter months fare better than those receiving prompt treatment of acute exacerbations. Further, can the lung function of these patients be preserved better by chemoprophylaxis ?

The British Tuberculosis Association (1960) report on chemotherapy in chronic bronchitis compared the effect of tetracycline $250 \mathrm{mg}$. b.d. with penicillin $\mathrm{V}$ potassium $312 \mathrm{mg}$. b.d. and a placebo in 226 patients. Treatment with penicillin or tetracycline reduced the loss of working days by about half compared with the controls. Neither drug significantly reduced the number of exacerbations, but both reduced their duration. The British Tuberculosis Association (1961) reported 519 patients who received in regimen $\mathbf{A}$ maintenance starch capsules with intermittent oral penicillin for exacerbations ; B, maintenance tetracycline with starch capsules for exacerbations; C, maintenance penicillin with again starch capsules for exacerba- 